
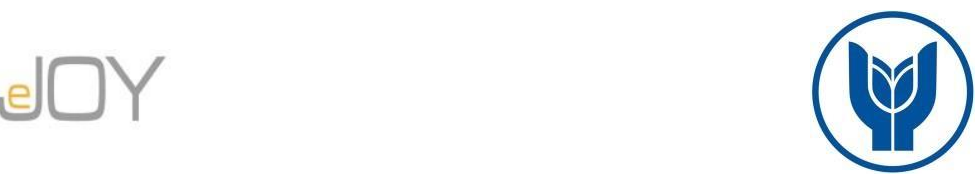

Özbozkurt, O., B., Kırmızısaç, E. / Journal of Yasar University, 2019, 14/55, 288-298

\title{
Stres Oluşturan Etmenlerin İş Performansı Üzerindeki Etkisi: Mersin İlinde Kuyumculuk Sektörü Yöneticileri Üzerine ${ }^{1}$
}

\author{
The Impact of Factors Causing Stress on Job Performance: On The Managers \\ of Jewelery Store in Mersin
}

\author{
Onur Başar ÖZBOZKURT, Çağ Üniversitesi, Türkiye, onurozbozkurt@cag.edu.tr \\ Emin KIRMIZISAÇ, Türkiye, ekirmizisac@gmail.com
}

\begin{abstract}
Öz: Bu çalışma, kuyumculuk sektöründe bireysel, örgütsel ve çevresel stres etmenlerinin kuyumcuların iş performansı üzerindeki etkisinin araştırllması ve ilgili alanyazında açıkça görülen eksikliğin giderilmesi amacıyla gerçekleştirilmiştir. Bu bağlamda, Mersin ilinde, en yüksek iş hacmine sahip beș kuyumcu ișletmesi yöneticisi ile derinlemesine görüșme yapılmıștır. Görüșmeler sonucunda elde edilen veriler, "NVivo 12” nitel analiz programı vasıtasıyla içerik analizine tabi tutulmuştur. Analiz sonuçları doğrultusunda, kuyumcu işletmesi yöneticilerinin iş performansına etki eden en önemli stres faktörlerinin, aile, is deneyimi ve kazanç (bireysel kaynaklı); sermaye, güvenlik ve mesleki yeterlilik (örgütsel kaynakl) ve politik ve ekonomik etmenlerden (çevresel kaynakli) oluştuğu görülmüşü̈r. Ek olarak, bu etmenlerin iş görenler üzerinde olumsuz, nötr ve ters u etkisinin
\end{abstract} olduğu tespit edilmiştir.

Anahtar Sözcükler: Stres, İs Performansı, Türk Kuyumculuk Sektörü, İsletme

Abstract: This study has been carried out with the purpose of identifying the impact of individual, organizational and environmental stress factors on job performance and being fulfilled to clear the need of research in the jewellery sector. In this scope, in-depth interviews have been conducted with the managers of five jewellery store that have the highest volume of business in Mersin. The data obtained from interviews has been analyzed via "NVivo 12" qualitative analysis program by conducting content analysis. According to the results of the analysis, it has been seen that the most important stress factors which have significant impacts on job performance of managers of jewellery store include, family, job experience and income (individual originated); capital, safety and professional competence (organizational originated), and political and economic factors (environment originated). Additionally, it has been identified that these factors have negative, neutral and inverted $u$ effects on the employees.

Keywords: Stress, Job Performance, Turkish Jewellery Sector, Organization

\section{Giriş}

Çalışma yaşantısı, bireylerin yaşamı boyunca önemli bir yere sahip olmaktadır. Bu bağlamda birçok etmen bireyin performansına yansıdığından, kaydedilen iş performansı örgütler için hayati bir önem taşımaktadır. Bu doğrultuda, bireylerin aile, iş ve çevreden kaynaklı olmak suretiyle karşılaştıkları problem alanları, bireyde stres olgusunun ortaya çıkmasına neden olmaktadır. Stres olgusu algısal bir süreç olduğu için bireyden bireye veya farklı çevresel etkenlere göre değişiklik göstermektedir (Radbeh, 2014: 3-6).

Stres, çalışanların örgüt içinde yorgunluk, yıpranma, iş tatminsizliği, çaresizlik, fiziksel bitkinlik, ümitsizlik gibi duygulara sebep olmakla birlikte, bireyleri iş yaşantısında, olumsuz tutumlara ve davranışlara da itmektedir. Bu durum, çalışanların yaptıkları işteki verimliliklerini ve istikrarlı bir çalışma ortamı elde edilmesini engellemektedir. Böyle bir iş ortamında, bireyin kendisinden ya da örgüt tarafindan kaynaklanan problem alanları, çalışanların performansını olumsuz yönde etkilemektedir.

Performansı etkileyen başlıca stres etmenleri ise, bireysel stres etmenleri, örgütsel stres etmenleri ve çevresel stres etmenlerinden oluşmaktadır (Aydın, Üçüncü ve Taşdemir, 2011: 390). Bununla birlikte, birey yaşantısı boyunca bu stres etmenlerine maruz kalmakta ve bireyin bununla mücadele etme gayreti içinde olduğu görülmektedir. Diğer taraftan, bireylerin iş yaşantısında görevlerini yerini getirirken karşılaştıkları stres etmenleri onları tetiklemekte ve performanslarını olumlu yönde artırabilmektedir (Tokay, 2000: 67). Ancak, stres seviyesi yükseldikçe bireyin performansı bu durumdan olumsuz şekilde etkilenebilmektedir (Ergeneli ve Karan, 1997: 140-151). Stresin performans üzerindeki etkisini ifade eden "ters u” kavramı ise, öncelik olarak bireyin karşılaştığı problemlerle mücadele etmeyi seçtiğini, başaramadığ 1 takdirde ise geri çekildiğini ve sonuçlarını kabullenmek zorunda kaldığını açıklamaktadır (Sullivan ve Bahagat, 1992: 357). Ayrıca, alanyazında, stresin iş performansı üzerinde herhangi bir etkisinin bulunmadığ1 (nötr) da ifade edilmektedir (Junqian, 2014: 72).

Diğer taraftan, sektörün doğal yapısından kaynaklı olarak baskın, hırsızlık, sahtecilik gibi arzu edilmeyen olayların, ilgili sektörün işletme yöneticilerini yoğun stres düzeyine maruz bırakması sebebiyle bu çalışmanın temelini kuyumculuk sektöründe faaliyet gösteren işletmeler oluşturmaktadır. Stres oluşturan etmenlerin kuyumcu işletme

${ }^{1} \mathrm{Bu}$ çalışma, “25.02.2019” tarihinde, Çă̆ Üniversitesi Sosyal Bilimler Enstitüsü İşletme Yönetimi Anabilim Dalı’nda tamamlanmış olan, “Türk Kuyumculuk Sektöründe Strese Neden Olan Etmenlerin Kuyumcuların Performansı Üzerindeki Etkisinin İncelenmesi: Mersin İlinde Faaliyette Bulunan Kuyumcular Üzerine Nitel Bir Araştırma” konulu yüksek lisans tezinin ilgili bölümlerinin yeniden gözden geçirilmesiyle hazırlanmıştır. 
yöneticilerinin iş performansları üzerine etkisine ilişkin herhangi bir bilimsel çalışmaya rastlanılamaması sebebi doğrultusunda, bu çalışma, alanyazında açıkça görülen eksikliğin giderilmesi amacıyla gerçekleştirilmiştir. Bu bağlamda, çalışmanın gerçekleştirildiği Mersin ilinde faaliyet gösteren kuyumcu işletmelerinin deneyimledikleri stres etmenlerinin (bireysel, örgütsel ve çevresel kaynaklı) kuyumcuların iş performansı üzerindeki etkisinin incelenmesi çerçevesinde, Mersin Ticaret ve Sanayi Odası ile Mersin Kuyumcular Esnaf ve Sanatkârlar Odası'nda kaydı bulunan 350 kuyumcu işletmesi arasından, iş hacmi en yüksek ilk on kuyumcu işletmesinin yöneticisi örnekleme dâhil edilmesine rağmen, beşinci işletme yöneticisi ile görüşme gerçekleştirildikten sonra, kavramların tekrar edildiği fark edilmiş ve beş işletmenin bu çalışma için yeterli olduğu tespit edilmiştir. Elde edilen veriler, nitel verilerin analiz edilmesine olanak sağlayan "NVivo 12" programı aracılığıyla içerik analizine tabi tutulmuştur. Bununla birlikte, nitel çalışmalarda birden çok veri toplama yönteminden faydalanılmasının, araştırmanın geçerliliğinde önemli bir katkısı olması bakımından, elde edilmiş olan veriler, alanyazın ve sektör raporları ile desteklenmiştir.

\section{Kuramsal Çerçeve}

\subsection{Stres Kaynaklart}

İş yaşantısında, bireylerin performansını birçok değişken etkilemekle birlikte, alanyazında yer alan temel stres etmenleri, bireysel stres etmenleri, örgütsel stres etmenleri ve çevresel stres etmenlerinden oluşmakta (Aydın, Üçüncü ve Taşdemir, 2011: 390) ve bahse konu temel stres etmenleri aşağıda yer almaktadır.

\subsubsection{Bireysel Stres}

Bireysel stres etmenleri kişinin fizyolojik ve psikolojik özellikleri ile ilgili olmaktadır. Kişilerin olayları algılama kapasitesi, düşünce şekli, olaylara anlam yükleme kabiliyeti ve bir olay karşısındaki dayanıklılık seviyeleri birbirinden farklı olarak gerçekleşmektedir (Kabul, 2016: 15). Stresi tetikleyen bireysel etmenlerin, genel olarak kişilik özellikleri, yaş, medeni durum ve cinsiyet, iş tatmini ve çalışma süresi, eğitim düzeyi, aile etmeni, ekonomik etmenler ve istihdam durumu adı altında incelendiği görülmektedir (Soysal, 2009: 29). Örneğin, kişilik özellikleri ebeveynlerden bireye kalıtımsal olarak aktarılmakla birlikte, kişinin içerisinde bulunduğu toplumdaki rolü ve etkileşime girdiği çevrenin de bireyin karakterinin şekillenmesinde etkisi bulunmaktadır (Engin, Calapoğlu, Seven ve Yörük, 2008: 39-43). Yaş etmeni, bireysel stres etmenleri arasında bir diğer önemli unsur olmaktadır. Yaş ilerledikçe insan vücudunda yaşanan fiziksel ve ruhsal değişimin, bireylerde stres seviyesini artırabilme etkisi bulunmaktadır (Aktaş, 2001: 35-37). Aile etmeni, bireylerin yaşantısında önemli bir yere sahip olmaktadır. Bireylerin kendi içinde yaşadıkları ilişkilerin şekli, aile bireylerinin talepleri, olanakları, yetenekleri, bilgi ve deneyimleri, algılamaları, sosyal ve kültürel değerleri ve dünya görüşleri ile beraber diğer kişilik özellikleri birbirinden farklılık göstermekte (Ekinci ve Ekici, 2003: 102) ve aile bireyleri arasında yaşanan olası problem alanları birey üzerindeki stresi artırabilmektedir.

Bireyler üzerinde stres oluşturan bir diğer faktör olan kazanç etmeni, bireyin gelir seviyesinin düşük olması gibi bir durumda, bireyin fizyolojik ihtiyaçlarını karşılayamamasına ve bireyin yoğun strese maruz kalmasına sebep olabilmektedir (Erdal, 2009: 38). Deneyim etmeni çerçevesinde ise, bireyin görevini ifa ettiği işin tekniği hakkında yeterli bilgi sahibi olamama, değer yargılarını anlayamama, hiyerarşik düzene adapte olamama gibi olumsuz durumlar, bireyler üzerinde stres yaratabilmektedir (Ekinci ve Ekici, 2003: 110-111).

\subsection{2. Örgütsel Stres}

İş yaşantısında örgütsel strese neden olan etmenleri inceleyen Luthans (2010: 284); idari politikalar ve stratejiler, organizasyon yapısı ve tasarımı, örgütsel süreçler ve çalışma koşullarının temel olarak stres yarattığını belirtmiştir. Örgütlerde yeterli sermayenin olmaması, önceden belirlenen örgütsel amaçlara ulaşmada başarısızlı̆̆a sebep olabilmektedir (Budak, 2015: 42). Örneğin, özellikle bu çalışmanın da temelini oluşturan kuyumculuk sektöründe sermaye etmeni, strese neden olan önemli bir faktördür. Kendirli ve Konak (2014: 2)'1n da belirttiği üzere, yeterli sermayenin var olmayışı ile oluşan stres, bireyler üzerinde baskı unsuru oluşturarak performansı olumsuz etkileyecektir. Diğer taraftan iş yerinde rahat ve huzurlu bir çalışma ortamının tesis edilememesi, olası güvenlik risklerine karşı gerekli tedbirlerin alınamaması da özellikle kuyumculuk gibi faaliyet alanlarında, stres yaratan ve performans üzerinde etkisi olan hususlardır. Zaman etmeni ise, örgütsel açıdan stres yaratan bir başka unsur olmakla birlikte, alıcı ile satıcı arasında önceden belirlenen zaman dilimi içerisinde, ürün teslimatının gerçekleştirilememesi durumunda performansı olumsuz etkileyebilecektir (Moore ve Tenney, 2012: 22). Böyle bir olumsuz durum, müşterinin satıcıya olan güvenini zedeleyebilecek ve müşterinin aynı örgütten alışveriş yapma eğilimini ve sürekliliğini etkileyecektir (Gundlach ve Cannon, 2010: 415-417).

\subsection{3. Çevresel Stres}

İnsanlar günlük hayatta ulaşım ve çevre sorunları, sosyo-kültürel sorunlar, küresel politik ve ekonomik olumsuzluklar ve teknolojik değişime adapte olamama gibi birçok problem alanı ile karşılaşabilmektedir (Ellison ve Maynard, 1992: 34; Can, 2005: 158-165; Gökgöz, 2013: 29). Örneğin ülkelerin ekonomisinde meydana gelen belirsizlikler, krizler, işsizlik, enflasyon, gelir seviyesinin düşüklüğü, yaşam standartlarının düşmesi ve hayat pahalılığı önemli birer stres kaynağı olmaktadır. Kriz dönemlerinde taleplerin azalması, iş olanaklarının güçleşmesine ve çalışanların stres altında 
görevlerini ifa etmelerine neden olmaktadır (Eren, 2007: 285). Buna ek olarak, uluslararası çevrede yaşanan veya politik güç ve gelişmelerden kaynaklı olumsuzluklar ise sektör gözetmeksizin işletmelerin faaliyetlerini kesintiye uğratabilmektedir (Özbozkurt, 2016: 65-215). Diğer taraftan teknoloji etmeni, sektörleri değişime uyum sağlamaya iten bir faktör olmakta ve bu değişime adapte olamayan işletmeleri olumsuz etkilemektedir.

\subsection{Stresin Performans $\ddot{U} z$ erindeki Etkisi}

Performans, bireyin belirli bir görev veya sorumluluğu yerine getirmede başarı derecesini ifade eden bir kavram olarak tanımlanmakta (George ve Jones, 2012: 158) ve örgütsel amaçların gerçekleştirilmesinde önemli bir etken olmaktadır. Bireylerin iş yaşantısında deneyimledikleri stresin performans üzerindeki etkileri, içinde bulunan durum ve şartlara, bireyin yapmakla yükümlü olduğu görevlere ve sahip olunan kişilik özellikleri ile algılama yapısına göre değişiklik göstermektedir (Eroğlu, 2004: 416).

Alanyazında stresin performans üzerindeki etkisine ilişkin dört temel bileşen bulunmaktadır (Tuten ve Neidermeyer, 2004: 27). Bu konuya dair belirtilen birinci görüş, ters u modelidir. Bu görüşe göre stres ile performans arasında ters u ilişkisi vardır (Sullivan ve Bahagat, 1992: 357). Stresin yüksek olduğu durumlarda bireyler enerjilerini; performanslarını sergilemekten öte, stresle başa çıkmak için harcarlar. Normal stres ortamında ise bireyler stresi yenmekten çok performanslarını artırma çabası içine girmektedir (Tokay, 2000: 67). İkinci görüş ise stres ile performans arasında doğru orantılı bir etkileşim olduğunu savunmaktadır. Stres seviyesinin düşük olduğu ortamda, bireyler rekabetle yüz yüze gelmedikleri için bireylerin performansında bir artış olmayacaktır. Orta düzeydeki stres ortamında, bireyler kısmi rekabeti tecrübe ettiklerinden ortalama performansın oluşması olasıdır. Stres ortamı yüksek olduğu durumda da, rekabet ortamı ve optimum performans ortaya çıkmaktadır (Gümüştekin ve Öztemiz, 2005: 283). Üçüncü görüş, stres ile performans arasında negatif bir ilişki olduğunu savunmakta ve iş stresinin örgüt ve örgüt üyeleri için işlevsel olmadığını ileri sürmektedir. Bu görüş, bireyin fazladan ürettiği enerjinin, ona zihinsel bir yük getirdiğini, bunun yarattığı gerilim ve olumsuz duyguların ise performansı olumsuz yönde etkilediğini savunmaktadır (Ergeneli ve Karan, 1997: 140-151). Diğer bir görüş ise, stresin iş performansıyla ilişkisi bulunmadığını savunmaktadır. Bu modelde, bireyin performansına engel olabilecek güçlükler göz ardı edilmekte, stresin varlığının ya da yokluğunun performansı etkilemeyeceği varsayılmaktadır (Gümüştekin ve Öztemiz, 2005: 283; Tokay, 2000: 68).

\section{Araştırma Metodolojisi}

\subsection{Araştırma Deseni ve Modeli}

Çalışmada nitel araştırma desenlerinden birisi olan Olgubilim (fenomenoloji)'den faydalanılmıştır. Olgubilim araştırmalarında veri kaynakları, araştırmanın odaklandığı olguyu yaşayan ve bu olguyu dışa vurabilecek veya yansıtabilecek bireyler ya da gruplardır (Şimşek ve Yıldırım, 2013: 80). Olgubilim çerçevesinde en çok kullanılan yöntemlerden birisi olan yarı yapılandırılmış görüşme tekniğine bu araştırma kapsamında başvurulmuş olup, araştırılan olguyu tanımamıza ve anlamamıza yardımcı olacak örnekler ve açıklamalar elde edilmiştir.

\section{2. Örneklem}

$\mathrm{Bu}$ araştırma kapsamında, Mersin ilinde kuyumculuk sektöründe faaliyet gösteren ve Mersin Kuyumcular ve Esnaf Odası'na bağlı olup Mersin Ticaret ve Sanayi Odası'nda kaydı bulunan yaklaşık 350 kuyumcu arasından beş kuyumcu ile görüşme gerçekleştirilmiştir. Aşağıda yer alan Tablo 1, araştırmanın nitel örneklem yapısını ifade etmektedir.

Tablo 1. Nitel Örneklem Yapısı

\begin{tabular}{|c|c|c|c|c|c|c|c|}
\hline Görüşme & Yaş & Deneyim & Faaliyet Alanı & Pozisyon & Kayıt/Not & Tarih & Süre (dk.) \\
\hline 1 & 51 ve üstü & 20 ve üzeri & Kuyumculuk & İş Yeri Sahibi & Not & 02.11 .2018 & 120 \\
\hline 2 & 41- 50 aras 1 & $11-20$ & Kuyumculuk & İş Yeri Sahibi & Ses Kayd 1 & 13.11.2018 & 90 \\
\hline 3 & $31-40$ aras 1 & $11-20$ & Kuyumculuk & İş Yeri Sahibi & Not & 22.11 .2018 & 110 \\
\hline 4 & $31-40$ aras1 & $6-10$ & Kuyumculuk & İş Yeri Sahibi & Ses Kaydı & 28.11 .2018 & 150 \\
\hline
\end{tabular}




\begin{tabular}{lllllll}
\hline 5 & 51 ve üstü & 20 ve üzeri $\quad$ Kuyumculuk & İş Yeri Sahibi & Not & 05.12 .2018 & 90 \\
\hline
\end{tabular}

Diğer taraftan, nitel araştırma genellenebilir sonuçlar üretme çabası gayretinde değil; bir olguyu, derinliğine ve kendi ortamı ve sınırlılığı çerçevesinde açıklama çabası içerisinde olmaktadır (Yıldırım, 1999: 11-16). Buna ek olarak, nitel araştırmalarda, verinin kalitesi ve miktarının derinliği veya genişliğinin örneklemden daha büyük önem arz etmesinin yanı sıra, araştırmacı, ortaya çıkan kavramlar ve süreçler birbirini tekrar etmeye başladığı zaman yeterli sayıda veri kaynağına, farklı bir ifadeyle katılımcı sayısına ulaştığına karar verebilmektedir (Yıldırım ve Şimşek, 2013: 143). Bu açıdan Mersin Kuyumcular Esnaf ve Sanatkârlar Odası'ndan elde edilen veriler doğrultusunda, Mersin'de iş hacmi en yüksek kuyumcu işletmecilerinden oluşan ilk on işletme yöneticisi örnekleme dâhil edilmesine rağmen, beşinci işletme yöneticisi ile görüşme gerçekleştirildikten sonra, kavramların tekrar edildiği görülmüş ve beş işletmenin bu çalışma için yeterli olduğu tespit edilmiştir.

\subsection{Araştırma Verilerini Toplama Yöntemi}

$\mathrm{Bu}$ araştırmada nitel araştırma desenlerinden biri olan olgubilimde, en sık kullanılan veri toplama araçları olan görüşme tekniğinden yararlanılmıştır. Görüşme, insanların bakış açıları, deneyimleri, duyguları ve algıların ortaya konulması noktasında faydalanılmakta olan güçlü bir yöntem olma niteliği taşımaktadır (Yıldırım ve Şimşek 2013: 99-102). Bu araştırmanın asıl problemine ilişkin sorular açık uçlu sorular ile sorulmuş ve yalnızca demografik bilgilerini elde etmek için kapalı uçlu sorular yöneltilmiştir. Diğer taraftan, görüşmeler kuyumcu işletmelerinde gerçekleştirildiğinden, kuyumcu işletmelerinin yoğunluğu sebebiyle iki iş yerine birden fazla gidilerek görüşmeler tamamlanmıştır.

\subsection{Araştırma Verilerinin Analiz Yöntemi}

Bu araştırma kapsamında, görüşmelerden elde edilen veriler, "NVivo 12" programı ile içerik analizine tabi tutulmuştur. Diğer taraftan, bu çalışma, nitel bir araştırma olarak gerçekleştirildiğinden, nicel geçerlilik ve güvenirlik testleri geçerli olmamaktadır. Nitel araştırmada geçerlilik, araştırdığı olguyu, olduğu biçimiyle ve olabildiğince yansız gözlemesi anlamına gelmektedir (Yıldırım ve Şimşek, 2013: 289-290). Ayrıca, görüşmelerden elde edilen verileri destekleyen çeşitleme, katılımcı teyidi gibi ek yöntemlere de başvurulmuştur. Buna ek olarak, pilot uygulama gerçekleştirilerek kodların ve görüşme formunun güvenirliği desteklenmiştir.

\section{Bulgular ve Değerlendirme}

\subsection{Performansa Etki Eden Bireysel Stres Faktörleri}

Bireysel stres faktörleri, kişilerin yeteneklerini sergilemesine engel olabilmekte ve iş performansını düşürebilmektedir. $\mathrm{Bu}$ çalışma kapsamında, kuyumculuk sektöründe performansa etki eden bireysel stres faktörleri, Şekil 1'de görülebileceği üzere sırasıyla kazanç etmeni, aile etmeni, tecrübe etmeni ve yaş etmeni şeklinde ortaya çıkmıştır. 
Özbozkurt, O., B., Kırmızısaç, E. / Journal of Yasar University, 2019, 14/55, 288-298

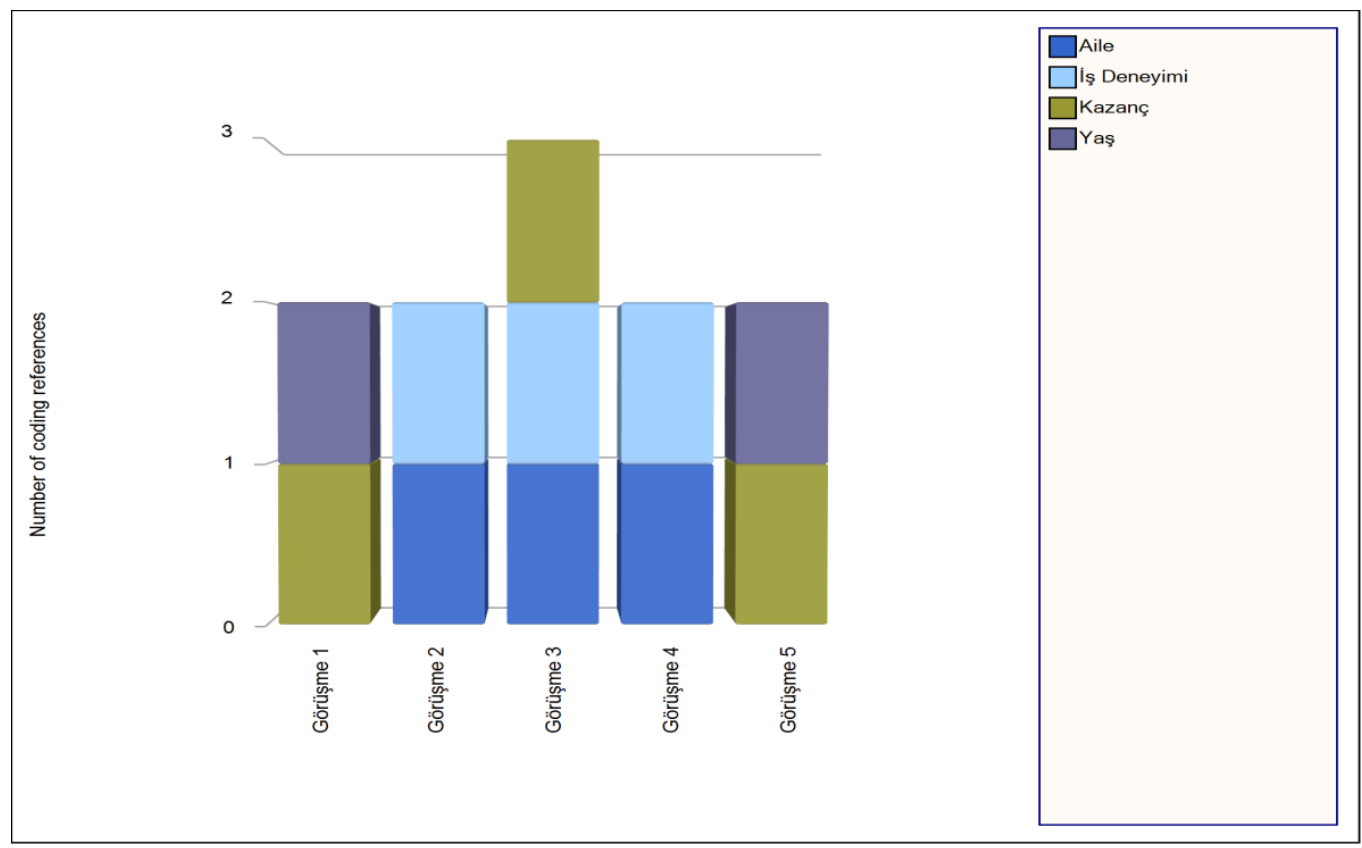

Şekil 1. Kuyumculuk Sektöründe Performansa Etki Eden Bireysel Stres Faktörleri

\subsubsection{Kazanç etmeni}

Kazanç, bireyin çalıştığ kurum ve sosyal yaşantısındaki statüsünü belirleyen önemli bir faktör olma niteliği taşımaktadır (Benligiray, 2013: 164) Böylece yaşam kalitesi artan çalışanın motivasyonu ve çalışma arzusu artacak, bu durum ise performansında olumlu etki sağlayacaktır. Öteki taraftan kazanç etmeninin yeterli düzeyde gerçekleşmemesi durumu, iş görenler üzerinde strese sebep olacaktır. Bu durumun, çalışmanın temelini oluşturan kuyumculuk sektöründe faaliyette bulunan bireylerin üzerinde stres oluşturduğu ve araştırmada görüşüne başvurulan katılimcılardan üȩünün (\%60) bu faktöre dikkat çektiği görülmektedir.

... Müşteri geldiğinde illa ki pazarlık yapmak ister ancak müşteri bunu makul fiyatlardan aşağısına çektiği zaman tabii ki buna yanaşamıyoruz. Çünkü altının belli bir hammadde değeri var ve bunun altına bazen fiyat veriyorlar. Biz böyle bir durumda ürünü pazarlayamıyoruz (Görüşme 5).

... Altın fiyatı yükseldikçe biz kendi işçiliğimizden feragat ediyoruz ama toptancı; işçi maaşlarının artması, yol, yiyecek, konaklama fiyatlarının artması nedeniyle işçilikleri artırmak istiyor. Ama biz bunu müş̧eriye yansıtamıyoruz. Bu durum ister istemez satış ve pazarlama performansınızı etkiler... (Görüşme 3).

\subsubsection{Aile ve Deneyim Etmeni}

İş yaşantısında deneyimlenen birçok bireysel etken, iş gören üzerinde strese neden olmakta ve bireyin iş performansını etkilemektedir. Bunların içinde aile etmeni önemli bir yere sahiptir (Ekinci ve Ekici, 2003: 102). Bu araştırma kapsamında, aile etmeninin performans üzerindeki etkisine dikkat çekmiş olan üç katılımcı (\%60) bulunmaktadır. Ancak, bazı kuyumcular, aile yaşantısında gerçekleşen olumsuzlukları iş yaşantısına yansıtmadıklarını aşağıda ifade etmişlerdir. Bu bağlamda, demografik sorulara verilen cevaplar doğrultusunda, 20 yıldan fazla kuyumculuk deneyimine sahip olan kuyumcuların bu stres etmeni ile iş performansları arasında nötr bir durum olduğu saptanmıştır. Bu durumu ifade eden katılımcının görüşüne aşağıda yer verilmiştir:

... Özel yaşantımı işime ve müşterilerime asla yansıtmam. Müş̧eriler geldiğinde elimden geldiğince her zamanki gibi davranırım çünkü işim konusunda taviz vermem (Görüşme 1).

Diğer taraftan, 20 yıldan daha az tecrübeye (\%60) sahip olan kuyumcularda da bu durumun iş yaşantılarına olumsuz olarak yansıdığı ve aile ilişkilerinden kaynaklı stres etmenlerinin de benzer olarak iş performanslarına olumsuz yönde etki ettiği görülmüştür:

... Ürünü pazarlarken moraliniz bozuksa aklınızda başka şeyler varsa tabi ki bu durum satış performansınızı kötü etkiliyor. Müşteriye ürünü iyi pazarlayamazsanız satamazsınız (Görüşme 3).

\subsubsection{Yaş Etmeni}

Bireylerin stres etmenlerine yükledikleri anlamlar yaşlarına göre de farklılıklar gösterebilmektedir. Strese neden olan benzer etmenler, genç birey için üzerinde düşünülmesi gereken bir durum değilken, orta yaş birey için stres yaratan bir 
unsur olabilmektedir (Aytekin, 2009: 56). Bu bağlamda, araştırma kapsamında görüşme gerçekleştirilmiş olan beş kuyumcu işletme yöneticisinden elde edilen veriler dikkate alındığında, kuyumcu işletmecileri arasında 50 yaş ve altı bireylerde strese dayanıklılık derecesinin daha yüksek olduğu tespit edilmiştir. Diğer taraftan, beş işletmeci arasında 50 yaş ve üstü bireylerde, kuyumcuların strese tahammül seviyelerinin daha düşük olduğunu (\%40) belirten örneklerden birisine aşağıda yer verilmiştir:

... Bir de müşteri bazen işçilikli ürünleri eline alıp bize, "bu ürünün ne işçiliği var ki işçilik alıyorsunuz diyor". İşte o zaman biz kendimizi bir arabanın duvara çarpması gibi hissediyoruz yani müşterinin altın hakkında bilgiye sahip olmaması bizi aşağılıyormuş gibi hissettiriyor. Bu durumların hepsi performansımızın düşmesine neden oluyor (Görüşme 5).

\subsection{Performansa Etki Eden Örgütsel Stres Faktörleri}

Örgütlerin kısa ve uzun vadeli hedeflerini eksiksiz yerine getirebilmesi için örgüt içinde sağlıklı işleyen bir yapıya ihtiyaç bulunmaktadır. Aksi takdirde, kurumlar hedefledikleri amaca ulaşmada güçlükler yaşayabilmektedirler (Michie, 2002: 69). Bu bağlamda, performansa etki eden örgütsel stres faktörleri, Şekil 2'de görüleceği üzere, başta sermaye etmeni (\%100) olmak üzere sırasıyla, güvenlik (\%100), mesleki yeterlilik (\%100), sağlık (\%60), güven ve süreklilik (\%60) ile zaman etmeninden (\%40) oluşmaktadır.

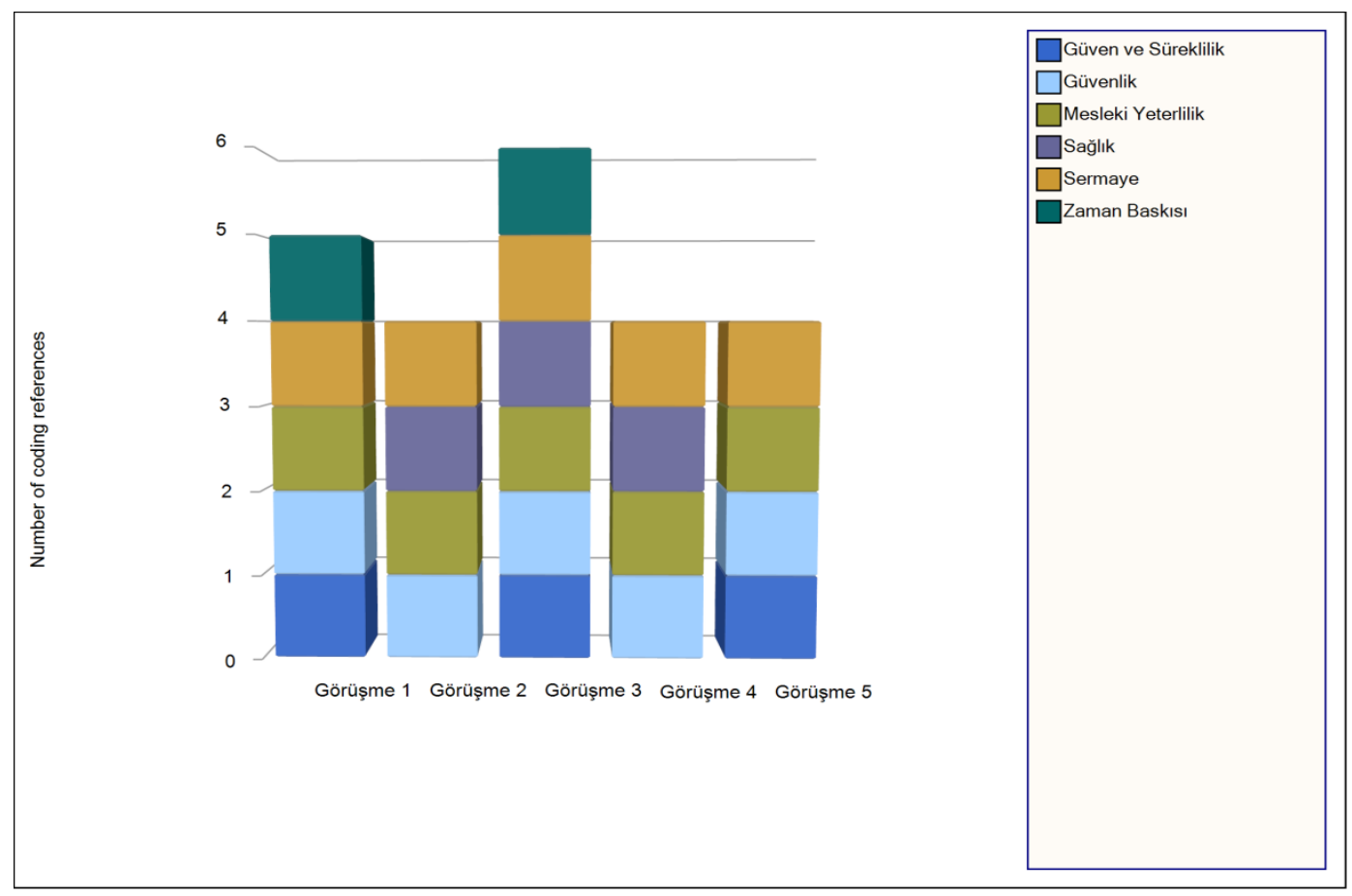

Şekil 2. Kuyumculuk Sektöründe Performansa Etki Eden Örgütsel Stres Etmenleri

\subsubsection{Sermaye Etmeni}

İşletmeler, hizmet sunduğu pazarda yeterli sermayeye sahip değilse kurum, örgütsel amaçlara ulaşmada başarısız olabilmektedir (Budak, 2015: 42). Özellikle kuyumculuk sektörü gibi ürün çeşidinin çok olduğu işlerde sermayenin az olması iş gören üzerinde baskıyı artırmakta ve performansı olumsuz etkileyebilmektedir (Kendirli ve Konak, 2014: 2).

Kuyumcu işletmeleri arasında yapılan mülakatlarda da sermayenin önemi ortaya çıkmış olup yetersiz sermayenin kuyumcunun üzerindeki baskıyı artırmasına rağmen ilk olarak performansı artırıcı bir etkiye sahip olduğu, ancak olumlu sonuca ulaşılamayacağı anlaşıldığında performans üzerinde negatif bir etkiye sahip olduğu katılımcı görüşlerinden anlaşılmaktadır.

... Kuyumculukta maddiyat önemlidir. Kasandaki öz sermaye çok olursa çeşidin çok olur ve müşteri geldiğinde de istediği ürünü vitrinden gösterebilirsin. Ancak ürün vitrininde yoksa müşteriyi kaybetme durumu ortaya çıkabilir. Bu da stresimizi artırıyor ve performansımızı etkiliyor (Görüşme 1).

... Benim şu an vitrinimde $10 \mathrm{~kg}$ altın var $20 \mathrm{~kg}$ olsa farklı olur ve neredeyse altın almak için gelen hiçbir müşterimi kaçırmam. Ya da her yerde aradığı bir ürünü bende bulan bir müşteri benden başka bir yerde artık alışveriş yapmaz. Bu durum bizim satış ve pazarlamamızı olumlu etkiler tabi. Zaten ürünün az olması başlı başına bir sıkıntı ki böyle bir durumda bazen müşteri içeri bile girmez (Görüşme 4). 


\subsubsection{Güvenlik Etmeni}

Riskli durumların yaşanma potansiyelinin yüksek olduğu sektörlerde, iş görenler kendilerini sürekli olarak tedirgin ve gergin hissedebilmektedir. Bu bağlamda oluşan olumsuz durum ise iş gören üzerinde stres etkisi yaratarak bireyin performansına olumsuz yönde etki göstermektedir. Doğası gereği, güvenlik kaynaklı risk düzeyi yüksek bir sektör olan kuyumculukta, hırsılık ve sahtecilik gibi arzu edilmeyen olaylardan dolayı katılımcıların \%100'ü bu güvenlik etmeninin önemli bir unsur olduğuna işaret etmiştir. Buna karşı ise, kuyumcuların güvenliklerini arttırmak için bir dizi önlem aldığı da aşağıda yer alan katılımcı ifadelerinden anlaşılmaktadır.

Bizim en büyük sorunumuz hırsızlık. Biz öncelikle müşterimize güveniriz ama tedbir de şarttır. Kuyumculukta, tezgâhta asla tek kişinin durmaması gerekir. Eğer aklında güvenlik sorunu varsa bu durum seni stres altına alıp pazarlamanı etkiler. Onun için güvenliği ikinci arkadaşa bırakıp sen pazarlama yaparsın... (Görüşme 2).

Bu durumla sıç̧a karşılaşıyoruz çünkü zaten sattığınız ürünler servet değerinde. Bu nedenle kuyumculuk riskli bir iştir ve güvenlik sorunu bizim için başlı başına büyük bir sorun teşkil eder (Görüşme 4).

\subsubsection{Mesleki Yeterlilik Etmeni}

Bir örgütte iş görenlerin faaliyette bulunulan alan ile ilgili olarak belirli bir bilgi birikimine sahip olması, gerek meslekleri açısından gerekse örgütsel açıdan önem taşımaktadır. Aksi bir durum ise, müşterilerde tatminsizlik yaratabilmekte ve bu durum, örgütsel amaçlara ulaşılmasını güç hale getirmektedir. Bu çalışma kapsamında, araştırmaya dâhil olan 5 katılımcının 5 'i $(\% 100)$ de mesleki yeterlilik etmeninin önemli bir faktör olduğuna dikkat çekmiş ve aşağıda örnek bir ifadeye yer verilmiştir.

Kuyumculuk sektöründe iş yeterliliği çok önemlidir. İş yeterliliği olmadığı takdirde müşterinize ürünün detaylarını hiçbir şekilde anlatamayacaksınız. Bu da bizim gibi perakende satış yapan kişiler için çok ciddi bir durumdur. Ürünü eğer pazarlayamazsanız ürün satamazsınız veya müşteriden ürün geldiği zaman tam olarak ürünün değerini hesaplayamazsanız ve zarar edersiniz... (Görüşme 5).

\subsubsection{Güven ve Süreklilik Etmeni}

Müşteriler açısından bir işletmeye olan güven duygusunun varlığı, kurumsal imajı olumlu yönde etkileyecek ve müşterinin devamlı olarak aynı işletmeden alışveriş yapma eğilimi konusunda tetikleyici bir etken olabilecektir. Bu durum ise iş görenlerin performansını artıııcı bir etki yaratacaktır. Aşağıda, birbirini tetikleyen güven ve süreklilik (\% 60) etmenlerine ilişkin örnek bir katılımcı ifadesine yer verilmiştir:

Bizim sektörde altını satmanın en önemli üç kuralı güven, samimiyet ve makul fiyattır. Bunu sağlarsanız hiçbir sıkıntı yaşamadan satışınızı yaparsınız... Tabi ki samimiyet burada en önemli durumlardan biridir. Müşteri samimiyetinize bakarak güvenir ve inanır. Müşteriye eğer o samimiyeti hissettirirseniz zaten sizden başkasına gitmez ve devamlı gelen müşteri ile de ne güven anlamında ne de fiyat anlamında bir sıkıntı yaşarsınız (Görüşme 3).

\subsubsection{Sağlık Etmeni}

Sağlık sorunları bireyin her alandaki faaliyetlerini kısıtladığ sahip olabilmekte ve zamanla hem fiziksel hem de ruhsal sağlık sorunları ile karşı karşıya kalabilmektedir. Çalışmanın temelini oluşturan kuyumculuk sektöründe de ilgili etmen, kuyumcuların performansının düşmesine sebep olabilen etmenlerden birisi olarak ön plana çıkmaktadır.

... Her gün işe gidip geliyor ve onca saat ayakta duruyoruz. Sonuçta ürünü oturarak pazarlayamazsınız ve bu durum sizi sosyal yaşantıdan mahrum bırakıyor. Kendinize çok vakit ayıramıyorsunuz bu da sizde her zaman bir yorgunluk hissi veriyor ve ister istemez aynı pazarlama gücünü kendinizde bulamıyorsunuz (Görüşme 4).

\subsubsection{Zaman Etmeni}

Günümüz koşullarında zaman, gerek bireysel gerekse örgütsel düzeyde önemli bir etken olarak karşımıza çıkmaktadır. Örneğin, zamanında teslimatı gerçekleştirilemeyen bir ürün, işletme ile müşteri arasında memnuniyetsizliğe sebep olabilmektedir. Böylesine bir zaman baskısının varlığı (\%40) ise iş gören performansını olumsuz yönde etkileyebilecektir. Bu sorunlar oluştuğunda aşağıdaki örnek ifadede de yer aldığı üzere, öncelikle kuyumcunun, müşteriyi ikna etmeyi öncelikli olarak gördüğü ve performansı doğrudan düşürmediği, müşteri ikna edilemediğinde ise iş görenin performansına bunun olumsuz olarak yansıdığı görülmektedir.

İlk etapta müşteriye ürününün neden gelmediği ile ilgili bilgi veririz ve müessesemiz adına özür dileriz. Eş değer ürünler varsa onlara yönlendirmeye çalışırız, müşteri kabul ederse... Etmezse bu da müşteriyle aramda hem sorun yaratır hem de üzerimdeki baskıyı artırır ve performansımı düşürür (Görüşme 1). 


\subsection{Performansa Etki Eden Çevresel Stres Faktörleri}

Çevresel stres etmenlerinden ekonomik ve siyasi istikrarsızlık iş gören üzerinde baskıyı artırırken iş görenin performansını da belirli derecede etkilemektedir (Gökgöz, 2013: 29). Örgütlerin, kısa ve uzun vadeli stratejilerini bu süreçleri takip ederek formüle etmeleri gerekmektedir. Bu etmenler araştırma katılımcıları tarafından, politik (\%100) ve ekonomik risk (\%100) ile teknolojik risk (\%40) olarak değerlendirilmiş olup Şekil 3 ’te yer almaktadır.

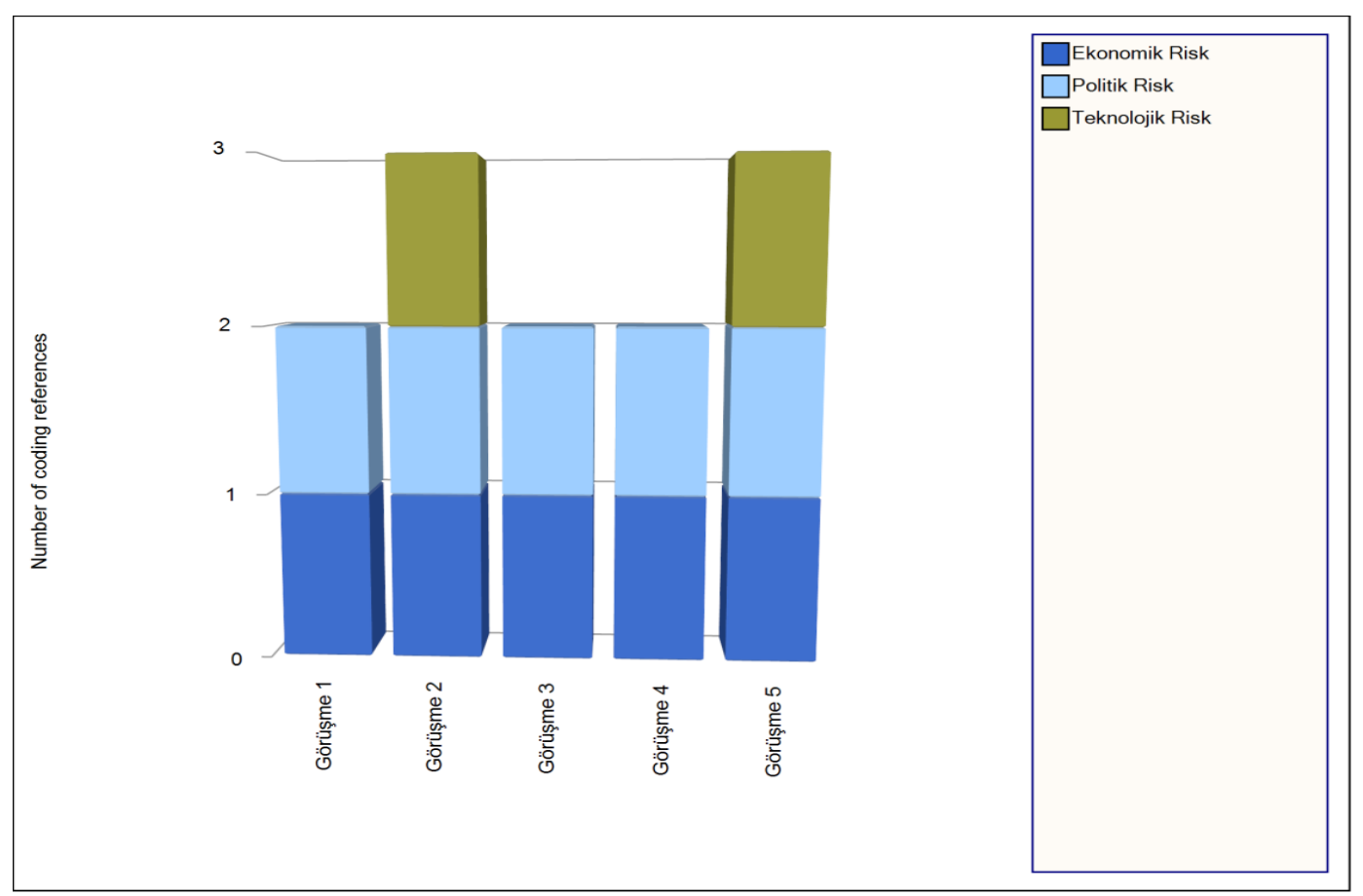

Şekil 3. Kuyumculuk Sektöründe Performansa Etki Eden Çevresel Stres Etmenleri

\subsubsection{Küresel Politik ve Ekonomik Risk}

Uluslararası anlamda yaşanan siyaset kaynaklı riskler makro-politik istikrarsızlığa neden olabilmekte ve bu durum ise toplumsal kalkınmayı engellerken insanların huzursuzluk içerisinde yaşamasına neden olmaktadır. Politik riski, politik güç ve gelişmelerin (terörizm, istikrarsızlık, hükümet politikaları vb.) işletmelerin faaliyetlerini kesintiye uğratması ihtimali şeklinde tanımlayan ve politik-ekonomik risklerin yatırımlar üzerindeki etkisini inceleyen Özbozkurt (2016: 65215) sektör gözetmeksizin, işletmelerin artan etkisiyle, politik ve ekonomik risklerin yıkıcı etkisine karşı bir dizi önlem geliştirmesinin gelecekte zorunluluk haline geleceğine dikkat çekmiştir.

Diğer taraftan, ekonomik istikrarsızlık durumu ise, işletmelerin üzerindeki baskıyı artırmakta ve satış ve pazarlamalarını olumsuz yönde etkileyebilmektedir. Özellikle de döviz kurunda bir artış meydana geldiğinde, ithal edilen malların maliyetinin artması gündeme gelmektedir. Maliyeti artan ürünün ise daha yüksek fiyatla satışı gerçekleşeceğinden, talep azalabilmekte ve piyasada kısa vadeli dış borçlar ve girdi maliyetlerinin artması sektörlere olumsuz yönde tesir etmektedir (Korkmaz ve Bayır, 2015: 71). Nitekim küresel anlamdaki politik riskler ve siyasi istikrarsızlıklar birçok ülkede olduğu üzere Türkiye'yi de yakından ilgilendirmektedir. Önemli ölçüde altın ve gümüş ithal eden ve ithal makineler kullanan Türk kuyumculuk sektörü de özellikle döviz kurundan kaynaklı olumsuzluktan etkilenmiştir. Bu bağlamda araştırmaya katılan kuyumculardan bazılarına ait örnek ifadeler aşağıda yer almaktadır:

... Bazen ürün tezgâhtayken bile fiyat değişebiliyor ve siz bunu müşterinize yansıtırsanız, müşterinin güvenini zedelersiniz. Yansıtmazsanız da zarar edeceksiniz ve her iki durum da sizin için sakıncalı. Böylece üzerinizdeki baskı had safhaya ulaşıyor. Ürünü satsam mı satmasam mı kârdayım diye düşünüyorsunuz. Çünkü beş dakika içinde 10 TL yükseldiği zamanlar oldu... Bu durum bizi olumsuz etkiliyor (Görüşme 3).

... Örneğin müşteri Mezitli'de arayıp bize çeyrek fiyatı soruyor oradan bizim bulunduğumuz ilçe Akdeniz'e gelmesi 30-35 dakika sürüyor ve bu esnada fiyat değişiyor. Bu durum ise müşteri ile aranızda sorun oluşturuyor ve sizi her yönüyle olumsuz etkiliyor. Biz de artık telefondan cevap vermiyoruz. Saat 10'da sattığınız ürünü saat 2' de yerine koyamazsanız stresiniz başlıyor (Görüşme 2).

\subsubsection{Teknolojik Risk}

Çalışan bireylerin üzerinde strese neden olan diğer bir etmen de teknolojik değişimlerin yarattığı risklerdir. Günümüzde teknoloji hızlı bir şekilde değişmekte; bunun sonucunda da işverenler verimliliği ve ürün kalitesini artırmak için teknolojiyi yakından takip edip gerektiğinde değişime ayak uydurmak durumundadır (Tomruk, 2014: 34). Nitekim, 
teknoloji etmeni, kuyumculuk sektöründe etkili bir satış ve pazarlama aracı olarak görülmektedir. Bu bağlamda, kuyumculuk sektörü, teknolojik değişimi yakından takip edip bu değişime adapte olanlara daha rahat bir ortamda satış ve pazarlama imkânı vermekte ve kuyumcu işletmecisi yöneticileri üzerindeki baskıyı azaltmaktadır. Günümüzde altın fiyatlarına internet üzerinden erişilebilmekte, dünyada ve ülkede üretilen ürünler tüketiciler tarafından çevrimiçi olarak takip edilmektedir. Bu nedenle kuyumcular, teknoloji ile birlikte yaşanan değişim rüzgârına adapte olmak zorundadır.

\begin{abstract}
... Müşteri ile aramızda en çok akıllı telefon sorunu yaşıyoruz. Eskiden müşteri bize güveniyordu, parayı bırakıp şu kadar altın istiyorum diyordu. Şimdi hem esnaf sayısının artması, hem teknolojinin gelişmesiyle müşteri fiyatı bize kendisi veriyor. $\mathrm{Bu}$ da daha az kazanca neden oluyor... Müşteri bazen gelip internette altının daha düşük fiyatta olduğunu söylüyor. İnternetteki, altının sadece has fiyatıdır. Yani işlenmemiş altının fiyatı bellidir. İnternette yüzüğün, kolyenin, küpenin, bileziğin işçiliği yazmaz; dükkân kirası yok, vergi yok, eleman derdi yok ve işlenmemiş bir altın yani aracıya para verilmiyor. Tabii ki fiyatı düşük olur. Bunu bazı müşterilerimiz anlayış ile karşılıyor bazıları ise aynı anlayışı göstermiyor (Görüşme 2).
\end{abstract}

\title{
5. Sonuç ve Öneriler
}

Stres, alanyazında yapılan tanımlardan da anlaşılacağı üzere günlük hayatta insanlar üzerinde önemli bir etkiye sahiptir. İş yaşantısında maruz kalınan stres ise, iş gören performansını etkilemektedir. Ancak bilinenin aksine stresin, iş görenlerin performansını her zaman olumsuz yönde değil olumlu yönde de etkilediği görülmektedir. Bu açıdan, alanyazında, stresin performans üzerindeki etkisinin, olumlu etki, olumsuz etki, nötr etki ve ters u olarak dört temel şekilde gerçekleşebildiği ifade edilmektedir (Tuten ve Neidermeyer, 2004: 27). Buradan hareketle, doğal özelliğinden kaynaklı baskın, hırsızlık ve sahtecilik gibi arzu edilmeyen olaylar sebebiyle yoğun stres düzeyine maruz kalan kuyumcu işletmelerinin deneyimledikleri stres oluşturan etmenlerin yöneticilerin iş performansları üzerindeki etkisinin incelenerek alanyazındaki eksikliğin giderilmesine katkı sağlayacağı düşünülen bu araştırma kapsamında ise, ilgili etmenlerin olumsuz etki, nötr etki ve ters u etkisi olarak üç farklı şekilde ortaya çıktığ görülmüştür.

Diğer taraftan, performansı etkileyen başlıca stres etmenlerinin; bireysel stres etmenleri, örgütsel stres etmenleri ve çevresel stres etmenlerinden meydana geldiği dikkat çekmektedir (Aydın, Üçüncü ve Taşdemir, 2011: 390). Bireysel stres etmenleri; temel olarak kişilik özellikleri, yaş, medeni durum ve cinsiyet, iş ile ilgili memnuniyet ve çalışma süresi, eğitim düzeyi, aile etmeni, ekonomik etmenler ve istihdam durumundan oluşmaktadır (Soysal, 2009: 29). Bu araştırma kapsamında ise, kuyumculardan elde edilen veriler ışığında, performansa etki eden bireysel stres etmenleri; kazanç etmeni, aile ve deneyim etmeni ve yaş etmeni başlıkları altında incelenmiş; bu etmenlerden kazanç etmeninin kuyumcuların çoğunun üzerinde yarattığı baskı ve bunun kuyumcuların performansına etkisi "ters u" şeklinde gerçekleşmektedir. Aile, deneyim ve yaş etmenleri kuyumcuların demografik özelliklerine göre birbirinden farklılık göstererek bireyleri olumsuz ya da nötr olarak etkilediği yapılan görüşmelerin içerik analizine tabi tutulması sonucunda ortaya çıkmıştır.

Örgütsel stres etmenleri ise alanyazında idari politikalar ve stratejiler, organizasyon yapısı ve tasarımı, örgütsel süreçler ve çalışma koşulları olmak üzere dört başlık altında ele alınırken (Luthans, 2010: 284), araştırmaya katılan kuyumcular ile yapılan görüşmeler sonucunda performansa etki eden örgütsel stres etmenlerinin, başta sermaye etmeni olmak üzere sırasıyla, güvenlik, mesleki yeterlilik, sağlık, güven ve süreklilik ile zaman etmeninden oluştuğu görülmektedir. Bu kapsamda, güvenlik ve mesleki yeterlilik etmeninin kuyumcular üzerinde doğrudan olumsuz etki yaratırken; sağlı etmeninin ise iki kuyumcuyu nötr, diğer kuyumcuları ise olumsuz etkilediği görülmektedir. Buna ek olarak güven, süreklilik ve zaman ile sermaye etmenlerinin kuyumcuların performansları üzerinde nötr veya öncelikle olumlu ancak amaçlanan hedefe ulaşılmadığı zaman olumsuz bir etki yaratmakta ve ters u etkisine sahip olduğu tespit edilmiştir.

Çevresel stres etmenlerinin performans üzerinde etkisi alanyazında ekonomik sorunlar, kentsel yaşam sorunlarının neden olduğu stres etmenleri, sosyo-kültürel ve teknolojik değişimlerden kaynaklı stres etmenleri şeklinde ele alınmaktadır (Ellison ve Maynard, 1992: 3-4; Can, 2005: 158-165; Gökgöz, 2013: 29). Bu araştırma sonucunda ise performansa etki eden çevresel stres etmenleri, küresel politik ve ekonomik risk ile teknolojik risk olarak ortaya çıkmıştır. Bu bağlamda, dünya genelinde yaşanan politik ve ekonomik olumsuzluklara ek olarak, ülkemize karş1 gerçekleştirilmek istenen kur saldırıları ile Türk Lirası'nın değer kaybına uğratılmaya çalışıldığı bir dönemde Türk kuyumculuk sektörünün önemli birer aktörü olan kuyumcular da olumsuz olarak etkilendiklerini belirtmişlerdir. Bu durum ise kuyumcuların iş streslerini artırmakta ve performans üzerinde "ters u" şeklinde bir etki göstermektedir. Teknolojik etmenlerde ise bu durum değişmekte ve etki; teknolojide yaşanan değişime adapte olan kuyumcularda olumlu olurken, adapte olamayan kuyumcularda ise olumsuz şekilde meydana gelmektedir.

Araştırmaya katılan kuyumculardan elde edilen veriler doğrultusunda, en çarpıcı problem alanlarından birinin müşterilerin, altının üretimi ve işçiliği hakkında yanlış veya eksik bilgiye sahip olması ya da hiçbir bilgiye sahip olmaması durumu ortaya çıkmıştır. Farklı bir ifadeyle, altının hammadde fiyatı ve altın ürünlerinin her birinin farklı işçilik fiyatlarına sahip olması, kuyumcunun ürünlerini pazarlama faaliyetlerini zorlaştırdığından, altının sürekli değişen hammadde fiyatı hakkında müşteri bilgilendirilmeli ve bu fiyatın o an için geçerli olduğu vurgulanmalıdır. Ek olarak, satış sırasında değişen kur fiyatlarından devamlı haberdar olunmalı ve satış sırasında da değişen fiyatlar hakkında müşteriye anında ve detaylı bilgi verilmelidir. Satışların belirli bir hakkaniyet duygusu ile her iki tarafı da tatmin edecek kâr oranı ile yapılması gerekmektedir. Bütün bu etkenler sağlandıktan sonra müşteri ile kuyumcu arasında bir güven 
Özbozkurt, O., B., Kırmızısaç, E. / Journal of Yasar University, 2019, 14/55, 288-298

bağı kurulacak ve yapılan satış işlemi baskı ve olumsuz bir etki olmadan gerçekleştirilecektir. Bu hususlar doğrultusunda, bu çalışmanın ilgili sektördeki uygulamalara katkı sağlaması beklenmektedir.

Diğer taraftan, görüşmeler iş yerlerinde gerçekleştirildiğinden, kuyumcu işletmelerinin yoğunluğundan kaynaklı olarak işletmelere birden fazla gidilerek görüşmelerin tamamlanması sebebiyle bu alanda gerçekleştirilmesi planlanan gelecek çalışmalarda, mümkün olması halinde işletme dışında bir yer seçilerek görüşmelerin gerçekleştirilmesi önerilmektedir. Ek olarak, kuyumcu işletmelerinin deneyimledikleri stres etmenlerinin yönetilmesi noktasında izlenmesi gereken stratejilerin araştırılması ve bu araştırmanın sadece perakende satış yapan kuyumcularla değil, aynı zamanda ürünleri işleyen atölye kuyumcuları da dâhil edilmek suretiyle daha kapsamlı bir örneklem ile gelecekteki araştırmaların yapılması ve alanyazındaki eksikliğin giderilmesi noktasında çalışmaların artırılması, araştırmacılara önerilmektedir. Son olarak, gelecek araştırmalarda bahse konu sektörde olduğu gibi yoğun bir stres düzeyine maruz kalan diğer sektörlerde de ilgili araştırmaların gerçekleştirilmesi önem taşımaktadır. 


\section{KAYNAKÇA}

Aktaş, A. (2001). Bir kamu kuruluşunun üst düzey yöneticilerinin iş stresi ve kişilik özellikleri, Ankara, Üniversitesi Siyasal Bilgiler Fakültesi Dergisi.

Aydın, A. \& Üçüncü, K., \& Taşdemir, T. (2011). Akademik Performansı Etkileyen Stres Kaynaklarının Belirlenmesine Yönelik Bir Alan Çalışması. Uluslararası Insan Bilimleri Dergisi, 8(2), 387-399.

Budak, E. Z. (2015). Kuyumculuk Sektör Raporu, Doğu Akdeniz Kalkınma Ajansı.

Can, H. (2005). Organizasyon ve Yönetim, Ankara, Siyasal Yayınları.

Ekinci, H. \& Ekici, S. (2003). "Yöneticiler Üzerindeki Etkileri Açısından Stres Kaynakları ve Bir Uygulama”, Sivas Cumhuriyet Üniversitesi, İİBF Dergisi, C:27, s.1.

Ellison, C. W., \& Maynard, E. S. (1992). Healing for the City. Grand Rapids: Zondeivan.

Engin, A. O., Calapoğlu, M., Seven, M. A., Yörük, A. K. (2008). Davranışlarımızın Genetik ve Çevresel Boyutları, Kafkas Üniversitesi Eğitim Fakültesi, Atatürk Üniversitesi Yabancı Diller Yüksek Okulu Kafkas Üniversitesi Fen Bilimleri Dergisi, C:1.

Eren, E. (2007). Örgütsel Davranış ve Yönetim Psikolojisi, İstanbul, Beta Yayınları.

Ergeneli, A., \& Karan, M. B. (1997). Strese Eğilimli Olmak Bakımından Bazı Bilişsel Alışkanlıklar İle İş Performansı İlişkisi: A Tipi Yatırım Fonu Yöneticilerine Yönelik Bir Çalışma. Amme İdaresi Dergisi, 30(4), 131-156.

Eroğlu, F. ( 2004). Davranış Bilimleri, İstanbul, Beta Yayınları.

George, J.M. \& Jones, G.R. (2012). Understanding and Managing Organizational Behavior, Sixth Edition, New Jersey, Pearson Education Inc.

Geylan, R., Tonus H. Z., Kağnıcıŏlu, D. Benligiray S., Baraz A. B. ve Ergun, Ö. Derya, N. (2013). Insan Kaynaklart Yönetimi, Eskişehir, Anadolu Üniversitesi Yayınları.

Gökgöz, H. (2013), Stresin Çalışanların Performansı Üzerine Etkisi, Trakya Üniversitesi, Yüksek Lisans Tezi, Edirne.

Gundlach, G.T. \& Cannon, J.P. (2010). “Trust but verify?” The performance implications of verification strategies in trusting relationship, Journal of Academy of Marketing Science.

Gümüştekin, G. E. \& Öztemiz, A.B. (2005), Örgütlerde Stresin Verimlilik ve Performansla Etkileşimi, Çukurova Üniversitesi Sosyal Bilimler Enstitüsü Dergisi, C: 14, s: 1.

Junqian, M. (2014). Stress: Friend or Enemy?. Journal of Educational and Social Research, 4(6), s. 275.

Kabul, M. (2016), Çalışanların Örgütsel Stres Kaynakları ve Stresle Başa Çıkma Yöntemleri, Beykent Üniversitesi Sosyal Bilimler Enstitüsü İşletme Yönetimi Anabilim Dalı Yönetim Organizasyon Bilim Dalı, Yüksek Lisans Tezi, İstanbul.

Kendirli, S. \& Konak, F. (2014). İşletme (Çalışma) Sermayesi Yönetimin Firma Performansı Üzerindeki Etkisi: Bist Gıda, İçecek Endeksi Uygulaması, Akademik Bakış Dergisi, s: 41.

Korkmaz, S. \& Bayır, M. (2015). Döviz Kuru Dalgalanmalarının Yurtiçi Fiyatlara Etkisi, Niğde Üniversitesi İktisadi ve İdari Bilimler Fakültesi Dergisi C:8,Sayı: 4.

Luthans, F. (2010). Organizational Behavior (12th Ed.). New York: McGraw Hills.

Michie, S. (2002). Causes and management of stress at work. Occupational and environmental medicine, 59(1), ss. 6772.

Moore, D. A. \& Tenney, E. R. (2012). Time pressure, performance, and productivity. In looking back, moving forward: A review of group and team-based research. Emerald Group Publishing Limited, 305-326.

Özbozkurt, O. B. (2016). Uluslararası İşletmecilik Faaliyetlerinde Politik Risk Yönetim Stratejilerinin Oluşturulması İle İlgili Türk İş Dünyası Ve Yatırımcıların Algısı Üzerine Nitel Bir Araştırma, Doktora Tezi, Mersin.

Radbeh, N. (2014). İ̧̧ Hayatında Stresin Performansa Etkileri, Yüksek Lisans Tezi, Yalova Üniversitesi, Yalova.

Soysal, A. (2009). İş Yaşamında Stres, çimento işverenler dergisi, İstanbul, C: 23, S:1.

Sullivan, S. \& Bahagat, R. S. (1992). Organizational Stress, Jop Stisfaction and Jop Performance: Where Do We Go From Here?, Journal Of Management, Vol: 18, No:2.

Tokay, T. (2000). Örgütlerde Performans İlişkisi, Yıldız Teknik Üniversitesi Sosyal Bilimler Enstitüsü, İşletme Anabilim Dalı, Yüksek Lisans Tezi, İstanbul.

Tomruk, Z. (2014). Akademisyenlerde Stres Kaynakları, Stres Durumunda ve Stresle Başa Çımada Gösterilen Davranışlarım İlişkisi: Yakın Doğu Üniversitesi Örneği, Gazi Üniversitesi, Sosyal Bilimler Enstitüsü, İşletme Anabilim Dalı, İnsan Kaynakları Bilim Dalı, Yüksek Lisans Tezi, Ankara.

Tuten, T.L. \& Neidermeyer, P.E. (2004). "Performance, Satisfaction And Turnover In Call Centers, The Effects of Stress and Optimism” Journal of Business Research, 57: 26-34.

Yıldırım, A. (1999). Nitel Araştırma Yöntemlerinin Temel Özellikleri ve Eğitim Araştırmalarındaki Yeri ve Önemi. Eğitim ve Bilim, 23(112), 7-17.

Yıldırım, A. \& Şimşek, H. (2013). Sosyal Bilimlerde Nitel Araştırma Yöntemleri, Ankara, Seçkin Yayıncılık. 